\title{
Erratum: Oligometastases in prostate cancer: restaging stage IV cancers and new radiotherapy options
}

Antonio José Conde Moreno*, Carlos Ferrer Albiach, Rodrigo Muelas Soria, Verónica González Vidal, Raquel García Gómez and María Albert Antequera

\section{Erratum}

After the publication of this work [1], we noticed that an incorrect version of Table two (Table 1 here) [1] was published. The correct version of Table two (Table 1 here) is provided here.

\section{Reference}

1. Conde Moreno AJ et al. Oligometastases in prostate cancer: restaging stage IV cancers and new radiotherapy options. Radiation Oncology. 2014;9:258.

\section{* Correspondence: antoniojconde@gmail.com}

Servicio de Oncología Radioterápica, Instituto Oncológico de Castellón "Dr. Altava", Consorcio Hospitalario Provincial de Castellón, Av. Dr. Clarà N 19, Castellón de la Plana 12002Castellón, Spain

\section{Submit your next manuscript to BioMed Central} and take full advantage of:

- Convenient online submission

- Thorough peer review

- No space constraints or color figure charges

- Immediate publication on acceptance

- Inclusion in PubMed, CAS, Scopus and Google Scholar

- Research which is freely available for redistribution

Submit your manuscript at www.biomedcentral.com/submit 
Table 1 Current Ongoing trials for Prostate Cancer Oligometastases in 2014 (www.clinicaltrials.gov)

\begin{tabular}{|c|c|c|c|c|c|c|}
\hline Study & $\begin{array}{l}\text { ClinicalTrials.gov } \\
\text { Identifier }\end{array}$ & Phase & Aim & Arms & Primary Objetives & Secondary Objetives \\
\hline $\begin{array}{l}\text { Radiotherapy for Oligometastatic } \\
\text { Prostate Cancer }\end{array}$ & NCT01859221 & 2 & $\begin{array}{l}\text { Efficacy and safety in } \\
\text { patients with prymary } \\
\text { active or not }\end{array}$ & 2: $\mathrm{CR}$ and $\mathrm{HN}$ & $\begin{array}{l}\text { Improvement in median } \\
\text { progression-free survival } \\
\text { in patients with metastatic } \\
\text { prostate cancer over historic } \\
\text { control rates in hormone } \\
\text { receptive and castration } \\
\text { resistant subgroups. }\end{array}$ & $\begin{array}{l}\text { Improvement in overall survival } \\
\text { of patients with metastatic } \\
\text { prostate cancer. }\end{array}$ \\
\hline
\end{tabular}

University of Florida

Stereotactic Radiosurgery in Treating Patients With Metastatic Breast Cancer, Non-Small Cell

Lung Cancer, or Prostate Cancer

NRG Oncology Foundation, Inc

Collaborator: NCI RTOG

Non-systemic Treatment for Patients With Low-volume Metastatic Prostate Cancer

University Hospital, Ghent

Phase II Study of SBRT as Treatment for Oligometastases in Prostate Cancer

GICOR

NCT02206334 1 Safety Study 1

NCT01558427 2 Defer the start of ADT

2: A. Active surveillance B. Surgical or radiotherapy treatment of metastases

NCT02192788 2 Safety and Efficacy Study determine the recommended SBRT dose for each of the metastatic locations being treated given the individual and overlapping fields when multiple metastases are treated with SBRT in a national clinical trials network setting.

Treatment failure rates in patients treated with stereotactic radiation for metastatic prostate cancer. after type of secondary outcome.

Quality of life in patients treated with stereotactic radiation for metastatic prostate cancer.

I. To estimate rates of $>=$ grade 3 (CTCAE 4.0) adverse events other than a dose-limiting toxicity which is possibly, probably, or definitely related to treatment and which occurs within 6 months from the start of SBRT to multiple metastases.

II. To estimate the rates of long-term adverse events occurring up to 2 years from the end of SBRT.

III. To explore the most appropriate and clinically relevant technological parameters to ensure quality and effectiveness throughout radiation therapy processes, including imaging simulation, patient immobilization, target and critical structure definition, treatment planning, image guidance and delivery.

Androgen deprivation therapy Quality of life free survival.

Local and symptomatic control of oligometastases treated by SBRT

Bio

\section{Biochemical progression rates}

Progression-free survival, 
Table 1 Current Ongoing trials for Prostate Cancer Oligometastases in 2014 (www.clinicaltrials.gov) (Continued)

Collaborators:

Chemotherapy-free survival and

overall survival.

SBRT-SG

Analyze toxicities and quality of life

of patients before and after treatment

SEOR

Consorcio Hospitalario

Provincial de Castellón

CR Castrate resistant, HR Hormone Receptive, NCI National Cancer Institut, RTOG Radiation Therapy Oncology Group, ADT androgen deprivation therapy

CTCAE 4.0: Common Terminology Criteria for Adverse Events SBRT-SG: Sterotactic Body Radiation Therapy Spanish Group

GICOR: Spanish Group of clinical Investigation in Radiation Oncology SEOR: Spanish society of Radiation Oncology 